\title{
THE CONCEPT OF PHYTOMELIORATION OF OPEN AGRICULTURAL LANDSCAPE ON EXAMPLE OF WOLA IDZIKOWSKA VILLAGE
}

\author{
Wojciech Przegon'1 , Roman Rybicki², Radomir Obroślak², Justyna Gabryszuk², Żanna Król²
}

1 Department of Agricultural Land Surveying, Cadaster and Photogrammetry, University of Agriculture in Krakow, Mickiewicza Str. 55/18, 31-120 Krakow, Poland, e-mail: w.przegon@interia.pl

2 Department of Environmental Engineering and Geodesy, University of Life Sciences in Lublin, Leszczyńskiego Str. 7, 20-069 Lublin, Poland, e-mail: roman.rybicki@up.lublin.pl, radomir.obroslak@up.lublin.pl, justynagabryszuk@gmail.com, zannakrol.up@o2.pl

Received: 2016.01.28

Accepted: 2016.03.04

Published: 2016.04.01

\begin{abstract}
The paper presents the project of land protection from erosion in Wola Idzikowska village. Because of the type of soils and topography, about $37 \%$ of the land is threatened by medium and strong water erosion. Due to the lack of windbreak barriers, $70 \%$ of the area is threatened by wind erosion. In Wola Idzikowska village in the years of 2004-2006 land consolidation was conducted. Anti-erosion protection systems were designed but never realized. The assessment of causes of this condition, as well as new system of anti-erosion phyto-control works have been done. Afforestation of about 4.1 hectares of land, mostly fallow lands and wastelands was designed. The possibility of introducing 7.60 kilometers of shelterbelts as a windbreak barriers was also shown.
\end{abstract}

Keywords: water erosion, wind erosion, phytomelioration, anti-erosion plantings.

\section{INTRODUCTION}

In the natural climatic conditions of Poland, forests are an eternal, most durable plant involucre of the area [Koreleski 1997]. Grubbing forests in order to acquire land for agricultural cultivation has resulted launching many negative processes. Original luxuriant vegetation was replaced by monoculture crops. Varied animal world of forest ecosystems, in large part have been replaced by plant pests_for which the main base of food are the same plants that are used by a man. As a result of lower water retention in arable land than in the forest, the risk of both drought and floods increase. In many places water and wind erosion of soil was launched [Ziemnicki 1967].

Radically stopping of negative changes in the environment, including erosion processes, it could be achieved by restoring permanent soil cover vegetation - the forest. Forest maintains the stability of slopes, most effectively protects the soil, has a high degree of interception of rainfall, regulates the drainage of water and have a serious impact on transport of suspension and dissolved substances in streams[Ziemnicki 1967]. Because of that, the most eroded lands are characterized by high-value soils for agriculture (eg. Uplands), therefore, significantly improving their woodiness (in a non-confrontational way to agriculture) seems unrealistic [Węgorek and Tałałaj 1995]. In such cases, ecological balance can be restored by shelterbelts. According to the regionalization needs of shelterbelts in Poland, developed by Zajączkowski [2005], there is a very urgent need for woodlots planting in the south-Polish uplands, foothills and in central Poland. These areas largely correspond to the regions that require the use of shelterbelts in order to prevent water erosion of soils. The author reports that needs in this respect occur on the area of 39.2 thousand $\mathrm{km}^{2}$, occupying $12.5 \%$ territory of Poland.

Shelterbelts located in the areas used for agriculture, can perform many functions in mitigating the effects of human activity. Properly shaped landscape and appropriate agricultural practices can reduce or even eliminate water and wind ero- 
sion, water pollution, dryness of the soil, depletion of species and diurnal variation of temperature, thereby improve conditions for plant growth and plant development [Siuta 2013, Weyssenhoff 2010, Węgorek 2008, Kapica et al. 1998, Ryszkowski and Życzyńska-Błoniak 1998, Orlik et al. 1996, Karg and Karlik 1993, Ziemnicki and Mozoła 1966].

The role of shelterbelts and their versatility (often larger than forests) has also been noticed in such documents as National Forest Policy, Second National Environmental Policy, National program to increase of woodiness. They were considered shelterbelts as equivalent to the forests and afforestation - conservation factor of agricultural production space [Węgorek 2008].

The aim of the study is to develop the concept of introduction of trees as barriers to counteract unfavorable phenomena in impoverished - monocultural agricultural landscape of Wola Idzikowska village.

\section{MATERIAL AND METHODS}

Wola Idzikowska village with an area of 551 hectares, is located in Fajsławice municipality in the center of the Lublin Upland (about 20 kilometers from Krasnystaw and about 40 kilometers southeast from Lublin)._In terms of tectonic, the terrain is located at the area of the socalled Lublin Trough, filled with chalk deposits, covered with tertiary and quaternary sediment patches [Kondracki 2002]. In the years 2004 2006, land consolidation was conducted in the analyzed village. Economic and spatial project assumptions, besides the improvement of the agrarian structure (new road system, new field pattern), partially also included protection of soil from erosion. Exclusion from agricultural use of soils located on slopes steeper than $15 \%$ (about 10 hectares) and their destination for afforestation or sodding were designed. Moreover, a 1.25-kilometers stipe of shelterbelts along the main road running through the hilltop (as an obstacle against the wind) was intended [Economic and spatial assumptions for the project of consolidation 2005]._For various reasons, these assumptions have not been realized.

This paper attempts to verify the rightness of the assumptions of consolidation project (in the aspect of protection of land against erosion) as well as re-engineering the system of phy- tomelioration works. New system of aforestation and tree plantings have been integrated into the existing terrain structure after consolidation, having regarded the existing recommendations as well as local natural and economic conditions. The graphic design of the project was done in EWMAPA. We used the draft general consolidation map, made by the Provincial Bureau of Surveying in Lublin. It was received from the county geodetic and cartographic resources in Krasnystaw (under license No. GG.6642.683.2015_0606_LC0).

The area of Wola Idzikowska village is heavily undulating with a difference in height up to 50 meters. At the central part of the area the highest elevation is located (about $230 \mathrm{~m}$ ) called "Kamienna Góra". Currently, there are no exploited quarries. The north-western slope of the hill is characterized by declines exceeding $15 \%$. It results in soils being subject to water erosion in grade 3 to 4 (average to strong erosion). Undulating and extensive plateau is located on the opposite side of the hill (Figure 1a). In the north - west, near the precinct's border, there is a valley of Marianka river (width about 100 to 300 meters).

Land use structure is as follows. Arable lands constitutes $86 \%$ of the area (473 hectares). Those lands are located as a range system, over a length of about $2.5 \mathrm{~km}$, from the buildings (situated above the valley of the river) to the southeastern border of the village. Grassland located mainly at the river valley, occupy $6 \%$ of the area (approximately 32 hectares). Forests and woodlands fragmented into several smaller complexes are located mainly at the river valley and locally on arable land, fallow land and wasteland (Figure $1 \mathrm{~b}$ and $1 \mathrm{c}$ ). These include the area of approx. 8 hectares, representing $1.5 \%$ of total area [Economic and spatial assumptions for the project of consolidation 2005].

In the village of Wola Idzikowska, mainly good quality lands exist. Approximately $87 \%$ of the acreage constitute the soils of class IIIa and IIIb. These are brown soils formed from loess and rendzina soils. They are included to the second complex of soil (wheat good - located beyond the slopes) and a third complex of soil (wheat defective - located on the slopes) - threatened by water erosion. By medium and strong water erosion is threatened about $37 \%$ of the land. Due to the lack of windbreak barriers (Figure 1a), 70\% of the area is threatened by wind erosion. 

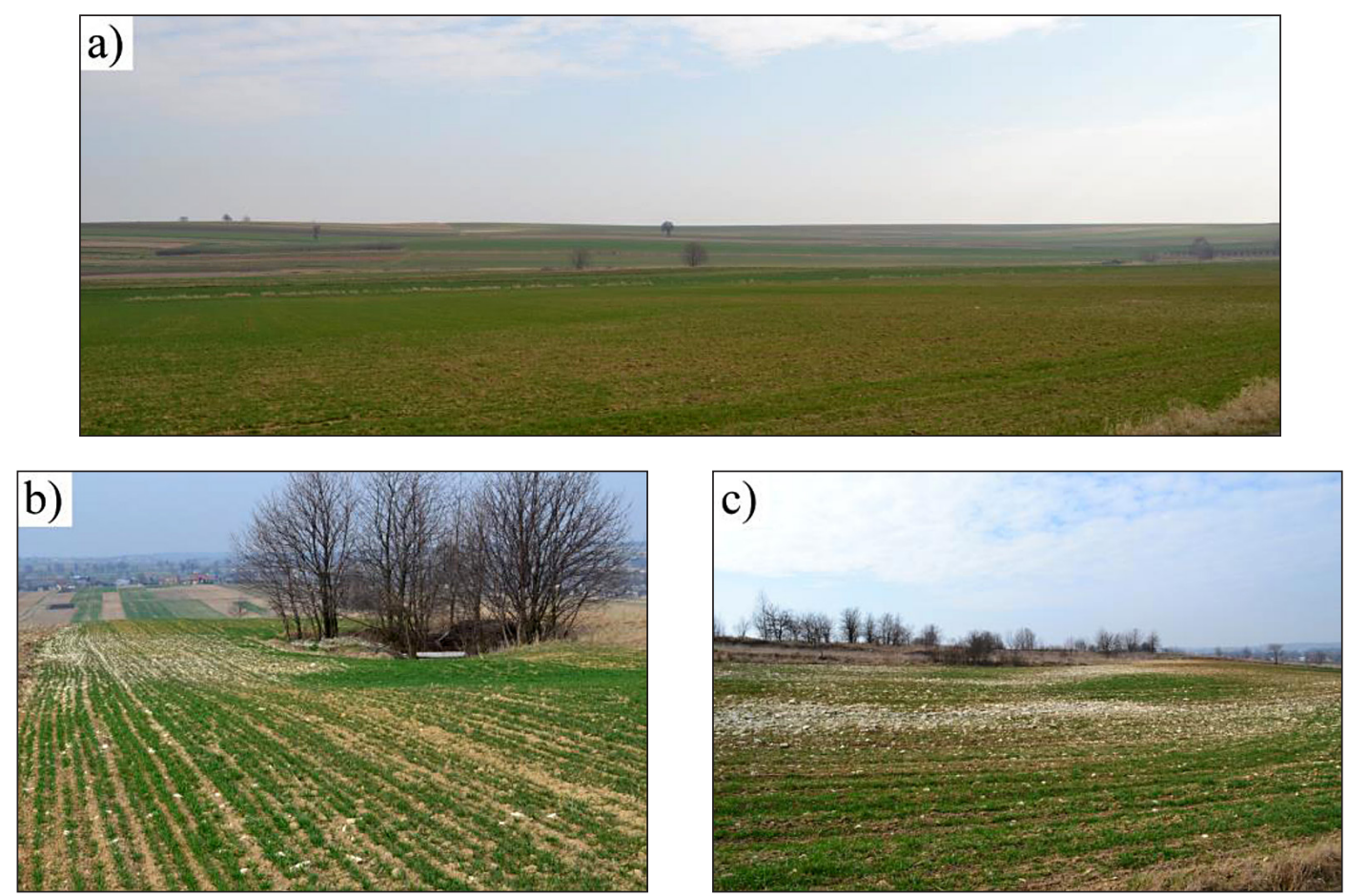

Figure 1. a) Monotonous landscape of Wola Idzikowska village; b) Planting at the abandoned quarry; c) Plantings on scarp and follow lands (foreground degraded arable land)

\section{RESULTS AND DISCUSSION}

Among two of phytomelioration assumptions of consolidation project, none were realized at the phase of post consolidation development._First of all, the project of exclusion from agricultural use and destination for afforestation of complex lands on steep slopes (fall of the ground more than $15 \%$ ) with wasteland and surfaces degraded after exploitation of limestone (total about 10 hectares) was not realized. The main cause of this was lack of acceptance from landowners. Discontinuation of cultivation could result in their loss of area payments. Moreover, communal authorities indicate the possibility of difficulties in financing the project. Finally, these surfaces are in agricultural use to the present, with up-downslope direction of the treatments. It must be assumed that this state will not change in the foreseeable future. Farmers will still not be interested in exclusion from cultivation of the whole of steep land. By the reason of the local spatial development plan, it is not possible to design anti-erosion, contour layout plots either.

At the present it can be concluded that excessive degradation of erosion limits only the size of the plots. Separated complexes of land threatened by erosion (roads on the borders) has a size that allows for plots lengths of about 200 to 400 meters (Figure 2). According to the Woch [2007] if it is not possible to change land layout, only shortening up-downslope plots (on slopes up to $20 \%$ inclination) is acceptable both by science and by practice.

However, the conducted investigation showed a tendency for excluding the use of certain area. These are mainly areas with degraded soils, as the effect of erosion and as residue from the exploitation of limestone. Emerges limestone rubble sometimes make any agricultural work impossible (Figure 1c). Moreover, surfaces excluded from agricultural use are narrow plots with high boundary strips, some grasslands and parts of plots with restricts access through existing old workings (marked on the map as a wasteland). The formed area of fallow lands is 1.89 hectares since 2006. Together with pre-existing wastelands $-3,34$ hectares. The forest serves as a barrier against wind. Additionally, by increasing the retention capacity of the landscape, the forest will prevent concentration of water runoff already in the upper parts of the slopes. This will reduce the threat of water erosion of the land located below.

Among the species for afforestation and plantings on such land as Wola Idzikowska village, Zajączkowski et al. [2001] recommend: sessile oak (Quercus petraea (Matt.) Liebl.), common 


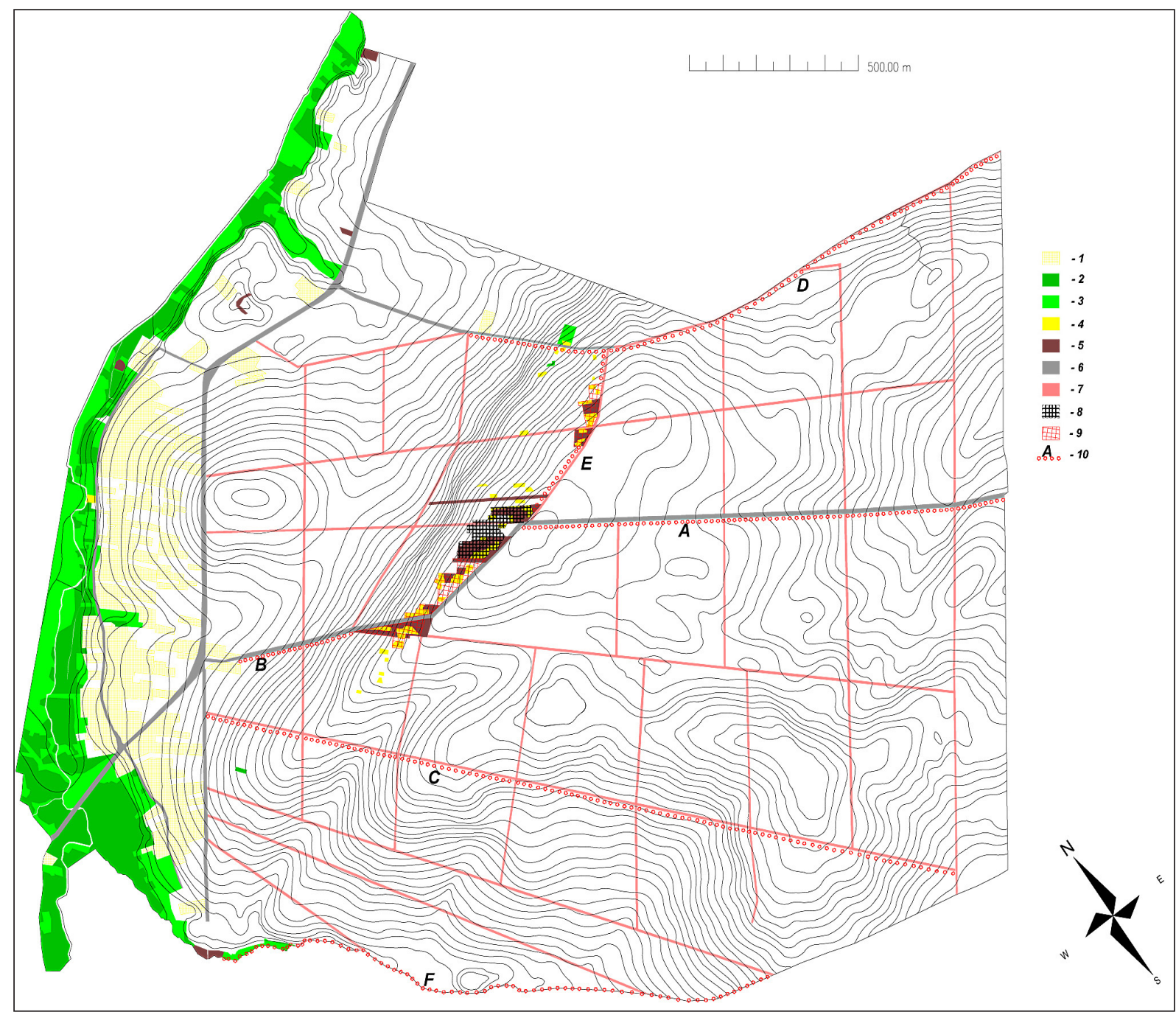

Figure 2. The area of Wola Idzikowska village with plotted projected shelterbelts: 1 - built-up areas, 2 - existing wooded areas at the bottom of Marianka valley, 3 - grassland, 4 - fallow lands, 5 - wastelands, 6 - hard-surfaced roads, 7 - ground roads, 8 - "Kamienna Góra" ecological use, 9 - designed afforestation, 10 - designed shelterbelts and sign of shelterbelt

oak (Quercus Robur L.), common birch (Betula pendula Roth), larch (Larix decidula Mill.), Norway spruce (Picea abies (L .) H. Karst.) and locally small-leaved linden (Tilia cordata Mill.), hornbeam (Carpinus betulus L.). In the contact zone of cultivated field - shrubs: Cornelian cherry (Cornus mas L.), Siberian peashrub (Caragana arborescens Lam.) and elder (Sambucus nigra L.).

Analyzing the problem of lack of implementation of the second project consolidation assumptions including phyto-melioration (shelterbelt project of main road running through the hilltop) is difficult to give a clear-cut cause. Inhabitants show tardiness of municipal authorities in the implementation of post consolidation development. In contrast, another reason may be a too indefinite note in the project. Only deciduous trees on both sides along the road were intended to be planted, without giving the species composition of trees. Neighboring landowners could have the fear that it may be poplar or ash - species negatively evaluated by farmers. In addition, although that road connects Wola Idzikowska with neighboring village Zosin, farm transport is main role of this road. Because of the necessity of passage of different widths of agricultural machinery, such roads should be planted by trees only on their one side.

Concerning the above, it was proposed that the main road should be planted with trees on one side, in two separate sections. The first 1.4 $\mathrm{km}$ long, is the section at part of hilltop up to the border of Zosin village (Figure 2 - designation A). The other is a 450 meter road section running up the slope, from the buildings to a hilltop part of Kamienna Góra - the area proposed for afforesta- 
tion (designation B, Figure 2). Trees in plantings should be located on the south side of the road. This will reduce the shading of adjacent fields and at the same time shading traffic lane. Planting should consist of a low foaming and slow-growing trees. Because of the car traffic, do not propose fruit-bearing species, eventually melliferous. According to the guidelines of Zajączkowski et al. [2001], following species were proposed: small-leaved linden (Tilia cordata Mill.), sycamore (Acer pseudoplatanus L.) and rowan (Sorbus aucuparia L. em. Hedl. 'Edulis).

Besides the shelterbelt designated by letters $\mathrm{A}$ and $\mathrm{B}$, it was proposed to introduce additional shelterbelt due to the need of further reduction of openness of the landscape and wind erosion. It will be shelterbelts along the road, parallel to the main road (designation $\mathrm{C}-$ Figure 2 ) with a length of 1.9 kilometers and along the road on the northeastern border of a village (designation D - Figure 2) - a length of 1.65 kilometers. Just like before, the shelterbelt needs to locate on the southern side of the road. Because these roads are only suitable for agricultural transport, species composition of tree plantings may contain, in addition melliferous, the fruit-bearing species. wild cherry (Cerasus avium (L.) Moench) and common pear (Pyrus communis L.) were mainly proposed - species occurring in large numbers at the bushes on wasteland. Additionally, small-leaved linden (Tilia cordata Mill.) and rowan (Sorbus aucuparia L. em. Hedl. 'Edulis). To reduce the required amount of land under trees, it was not proposed to introduce shrubs (even under the canopy of trees). Research conducted by Węgorek and Rybicki [2006] has shown that openwork shelterbelt with negligible amounts of shrubs at the undergrowth, positively affect the distribution of snow cover, even at the definitely absence of winds blowing from only one direction. It has been demonstrated that near such shelterbelts, snow cover is fairly evenly spread without explicitly increase of thickness of the snow at neighborhood of trees (formation of snowdrifts), as it happened at the compact shelterbelts with shrubs at the undergrowth.

Besides the listed, the introduction of 400 meters of double row shelterbelt (row of trees and shrubs row) was proposed along the field indispensable service road (designation E Figure 2). This road is limited on the south side from the top, complex plots threatened by erosion. On their side a shelterbelt should be also made. The proposed shelterbelt, as a substitute of the forest (instead afforestation proposed at the project of consolidation) will perform protective function and the function of an ecological corridor connecting planting " $D$ " with a newly projected afforestation. In addition to the proposed species of trees, at the row reserved for shrubs (from the road side) a Romanas rose (Rosa rogusa Thunb) was proposed to be introduced. It is a shrub with high aesthetic value, constitutes an additional source of food for animals [Zajączkowki et al. 2001]

The last proposed is the shelterbelt (length about $1.7 \mathrm{~km}$ ) along the northwestern border of the village (designation $\mathrm{F}$ - Figure 2). Besides of protecting aspects or possibility of underscore the boundary line of the precinct, this location mainly may be without conflicts with the interests of agriculture [Rybicki 2006]. Just like in the planting "D", also in this case, under the canopy of fruitbearing and melliferous trees, shrubs, for example Romanas rose, should be introduced.

\section{CONCLUSIONS}

The need to introduce anti-erosion shelterbelt, in practice is often not appreciated. At the same time existing shelterbelt are devastated or eliminated. Research on shelterbelts shows that they are necessary to improve ecological conditions in areas threatened and degraded by water and wind erosion [Węgorek 2008, Karg and Karlik 1993, Ziemnicki and Mozoła 1966].

The proposed conception of phyto-melioration of landscape of Wola Idzikowska village, is designed primarily to organize the structure of land use (elimination of fallow lands and wastelands), shape microclimate, habitat and biocenotic conditions, and reduce the risk of wind and water erosion. Additionally, production and socio-cultural functions of shelterbelt are important.

Afforestation of about 4.10 hectares of land located at upper part of the slope, including 1.26 hectares of fallow lands and 1.66 hectares of wastelands was proposed. Necessary to introduce are also shelterbelts: 1.95 kilometers along the main road, 3.95 kilometers along other agricultural roads (ground roads) and 1.70 kilometers along the border of the village. The total length of shelterbelt network is 7.60 kilometers.

Considering the difficulty of realizing the assumptions of consolidation project in the past, also in this case of phyto-melioration may 
encounter social resistance. The reluctance of farmers to shelterbelts, primarily due to the fear of yields decreasing in their neighborhood. Research results of Orlik et al. [1996], confirmed by Kapica et al. [1998] show that these fears are somewhat exaggerated. In the case of shelterbelts on chalk rendzinas, the decline in yields (relatively insignificant) ranged no more than 0.25 height of shelterbelt. In the case of surficial plantings on the black earth, yields discount exists only at the contact zone with plantings ("clipping belt"). Decreasing of the range of negative effects on yields (compared to previous reports), probably due to the use of modern methods of cultivation, rational fertilization and plant protection.

In reducing negative impacts of midfield shelterbelts on adjacent fields, an important care treatment should also be formation of shelterbelt walls [Węgorek 2008]. Appropriate cut forming, will prevent an excessive spread of shelterbelt and shading of crops neighboring through the branches - the main cause of the reduction of yields in the neighborhood of shelterbelts.

\section{REFERENCES}

1. Economic and spatial assumptions for the project of consolidation 2005. Provincial Bureau of Surveying in Lublin. Typescript [in Polish].

2. Kapica K., Obroślak R., Węgorek T. 1998. Plonowanie pszenicy ozimej w sąsiedztwie zadrzewienia śródpolnego na rędzinach w Nowosiółkach koło Chełma. Bibl. Fragm. Agronom. 4A. 361-369.

3. Karg J., Karlik B. 1993. Zadrzewienia na obszarach wiejskich. Wyd. Zakł. Bad. Środow. Roln. i Lesn. PAN, Poznań.

4. Kondracki J. 2002. Geografia regionalna Polski. Wydawnictwo Naukowe PWN, Warszawa.

5. Koreleski K. 1997. Ochrona gruntów przed erozją w gospodarce przestrzennej. Roczniki AR w Poznaniu, CCXCIV. 195-202.

6. Orlik T., Popławski E., Węgorek T. 1996. Plonowanie pszenicy ozimej i rzepaku ozimego w sąsiedz- twie zadrzewień przeciwerozyjnych na rędzinach. Ogólnopolskie Sympozjum Naukowe. „Ochrona Agroekosystemów Zagrożonych Erozją". Cz. 1. IUNG Puławy, 65-74.

7. Rybicki R., 2006. Zagospodarowanie gruntów zagrożonych erozją w świetle rolnictwa zrównoważonego. Inżynieria Rolnicza, 6, 231-239.

8. Ryszkowski L., Życzyńska-Błoniak I. 1998. Ograniczenie zanieczyszczeń obszarowych przez bariery biogeochemiczne. In: L. Ryszkowski, S. Bałazy (Eds.) Kształtowanie środowiska rolniczego na przykładzie Parku Krajobrazowego im. gen. D. Chłapowskiego. Zakł. Bad. Środ. Leśn. PAN. Poznań, 67-80.

9. Siuta J. 2013. Fitomelioracja środowiska i krajobrazu niezbędnikiem cywilizacji. Inżynieria Ekologiczna, 34, 53-61.

10. Weyssenhoff H. 2010. Zadrzewienia - stary sposób na nowe problemy. In: Uwarunkowania ochrony i restytucji zadrzewień na obszarach wiejskich. Red. S. Bałazy. Inst. Środ. Roln. i Leśn. PAN. Poznań, 139-144.

11. Węgorek T. 2008. Biologiczne metody zmniejszania zagrożenia gleb erozją wodną (fitomelioracje). In: Problemy erozji gleb w procesie przemian strukturalnych na obszarach wiejskich. Studia i Raporty IUNG-PIB. 10, 123-148.

12. Węgorek T., Rybicki R. 2006. Wpływ budowy zadrzewienia śródpolnego na kształtowanie się pokrywy śnieżnej. Acta Agroph. 7(1), 165-273.

13. Woch F. 2008. Urządzenioworolne metody zmniejszania zagrożenia erozyjnego gleb. In: Studia i Raporty IUNG-PIB, 10, 79-101.

14. Zajączkowski K. 2005. Regionalizacja potrzeb zadrzewieniowych w Polsce. Prace Instyt. Bad. Lesn., Rozpr. i monogr. 4, IBL, Warszawa.

15. Zajączkowski K., Tałałaj Z., Węgorek T., Zajączkowska B. 2001. Dobór drzew i krzewów do zadrzewień na obszarach wiejskich. Wyd. IBL, Warszawa.

16. Ziemnicki S. 1967. Melioracje przeciwerozyjne. Wyd. PWRiL, Warszawa.

17. Ziemnicki S., Mozoła R. 1966. Wprowadzanie zadrzewień przeciwerozyjnych. Wiad. IMUZ. T. VI, z. 3, 157-178. 